\title{
Simultaneous and Serial Measurement of Serum Levels of Human Placental Lactogen, Beta-Human Chorionic Gonadotropin and Unconjugated Estriol Levels in Pregnant Women
}

\author{
Nobuaki Furuhashi, Yoshinobu Tachibana, Osamu \\ Shinkawa, Masunori Hiruta, Tomomi Takahashi and \\ Mikio TanaKa \\ Department of Obstetrics and Gynecology, Tohoku \\ University School of Medicine, Sendai 980
}

\begin{abstract}
Furuhashi, N., Tachibana, Y., Shinkawa, O., Hiruta, M., Takahashi, T. and Tanaka, M. Simultaneous and Serial Measurement of Serum Levels of Human Placental Lactogen, Beta-Human Chorionic Gonadotropin and Unconjugated Estriol Levels in Pregnant Women. Tohoku J. exp. Med., 1984, 144(2), 211-215 - Serum levels of human placental lactogen (hPL), beta-human chorionic gonadotropin $\left(\beta\right.$-hCG) and unconjugated estriol $\left(\mathrm{E}_{3}\right)$ were measured simultaneously and serially in regular menstrual late pregnant women ( 155 samples) by radioimmunoassay. The peak of $\beta$-hCG level was shown at 37 weeks' gestation. After that, there was a moderate decline of the $\beta$-hCG level. Serum hPL showed the peak at 30 weeks' gestation. The level of unconjugated $\mathrm{E}_{3}$ rose toward 41 weeks' gestation. In the 155 samples, there were significant positive correlations among these hormone levels. Also, there were highly significant positive correlations between placental weight and these three hormone levels. Only unconjugated $\mathrm{E}_{3}$ level which was obtained within a week before the onset of labor had a significant positive correlation with birth weight. These data suggest that even in late pregnancy, maternal $\beta$-hCG makes a peak and may change parallel with hPL and unconjugated $\mathrm{E}_{3}$. Only the unconjugated $\mathrm{E}_{3}$ level may be affected by fetal growth. - human placental lactogen; beta-human chorionic gonadotropin ; unconjugated estriol ; maternal blood
\end{abstract}

There were numerous publications discussing normal values for serum human placental lactogen $(\mathrm{hPL})$ and unconjugated estriol $\left(\mathrm{E}_{3}\right)$ during late pregnancy (Lindberg and Nilsson 1973; Cleary and Young 1974; DeHertogh et al. 1975; Katagiri et al. 1976 ; Leuitz and Young 1977; Ottesen and Lebech 1979; Zlatnik et al. 1979; Varner and Hauser 1981). The daily excretions of serum hPL and unconjugated $\mathrm{E}_{3}$ are considered to be indices of fetal well-being in late pregnancy. Studies on the measurement of urinary $\mathrm{E}_{3}$, serum estrogens are inconclusive and

Received for publication, February 10, 1984. 
difficult to interpret. Obstetricians need more reliable tools with which to assess fetal well-being. No single laboratory test has a proven predictive value for assessing the complex fetal-maternal-placental function. The aim of the present study is to assess fetal well-being by modifications in the level of hPL, betahuman chorionic gonadotropin $(\beta-\mathrm{hCG})$ and unconjugated $\mathrm{E}_{3}$. There were several reports in measuring normal values for serum $\beta$-hCG in late pregnancy (Franchimont and Reuter 1972; Ashitaka et al. 1973; Vaitukaitis 1974; Hagen and McNeilly 1975; Good et al. 1977 ; Mputu et al. 1981). In this study, we have measured simultaneously and serially the maternal serum $\beta$-hCG, hPL and unconjugated $\mathrm{E}_{3}$ levels which were obtained in late pregnancy and investigated correlations among these hormones and between placental weight, birth weight and the levels of these hormones which were measured a week defore delivery.

\section{Materials and Methods}

Subjects. Subjects were 27 normal pregnant women who had had a regular menstrual cycle and gave a consent to collect serial blood samples (155 samples in total). The mean birth weight was $2450 \pm 80.6 \mathrm{~g}(n=27$, mean \pm s.E. $)$, and the mean placental weight was $605.7 \pm 19.7 \mathrm{~g}(n=27)$. Blood samples were centrifuged and kept at $-20^{\circ} \mathrm{C}$ until assay.

Radioimmunoassay. Serum $\beta$-hCG was measured as previously reported (Furuhashi et al. $1982 \mathrm{a}, \mathrm{b})$. Serum $\mathrm{hPL}$ and unconjugated $\mathrm{E}_{3}$ levels were measured by radioimmunoassay Kit (Amersham International, Ltd., England). The coefficients of variation of these methods were less than $15 \%$.

Statistical analysis. Statistical analysis was performed with Student's $t$-test. Correlation coefficients and analysis of variance and covariance were calculated by a microcomputer TRS-80 (Radio Shack, Fortworth, Texas, USA).

\section{Results}

Table 1 shows the hPL, $\beta$-hCG and unconjugated $\mathrm{E}_{3}$ levels in the maternal serum corresponding to gestational age for their pregnancies. The peak level of $\mathrm{hPL}$ was $7.3 \pm 0.3 \mu \mathrm{g} / \mathrm{ml}(n=25$, mean \pm S.E. $)$ at 38 weeks' gestation. This level was significantly $(p<0.05)$ higher than that at 32 weeks' gestation $(5.1 \pm 0.1 \mu \mathrm{g} /$ $\mathrm{ml}, n=8)$. After 38 weeks' gestation there was a moderate decrease in hPL level to $6.0 \mu \mathrm{g} / \mathrm{ml}$ at 41 weeks' gestation. The peak of $\beta$-hCG $(n=23,9.2 \pm 0.4 \mathrm{IU} / \mathrm{ml})$ was observed at 37 weeks' gestation. This level was significantly $(p<0.01)$ higher than that at 32 weeks' gestation $(n=8,6.6 \pm 0.3 \mathrm{IU} / \mathrm{ml})$. After 37 weeks' gestation there was a moderate decrease in $\beta$-hCG level to $6.4 \mathrm{IU} / \mathrm{ml}$ at 41 weeks' gestation. There was no sex difference for maternal $\beta$-hCG level due to fetal sex. The level of unconjugated $\mathrm{E}_{3}$ rose towards 41 weeks' gestation. The mean level of unconjugated $\mathrm{E}_{3}$ at 41 weeks' gestation $(n=4,23.5 \pm 1.6 \mathrm{ng} / \mathrm{ml})$ was significantly $(p<0.01)$ higher than that at 32 weeks' gestation $(n=8,8.4 \pm 0.1 \mathrm{ng}$ ) $\mathrm{ml})$.

In 155 maternal samples, there were significant positive correlations between unconjugated $\mathrm{E}_{3}$ level and $\beta$-hCG, hPL level, respectively as shown in Table 2. A highly significant positive correlation $(n=155, r=0.853, p<0.001)$ was also 
TABLE 1. Maternal serum $h P L, \beta-h C G$ and unconjugated estriol levels by week' gestation

\begin{tabular}{|c|c|c|c|c|c|c|c|c|c|c|c|}
\hline & \multicolumn{10}{|c|}{ Gestational week } \\
\hline & & 32 & 33 & 34 & 35 & 36 & 37 & 38 & 39 & 40 & 41 \\
\hline \multicolumn{2}{|c|}{ Number of subjects } & 8 & 8 & 11 & 15 & 24 & 23 & 25 & 20 & 14 & 4 \\
\hline \multirow{2}{*}{$\begin{array}{c}\mathrm{hPL} \\
(\mu \mathrm{g} / \mathrm{ml})\end{array}$} & Mean & 5.1 & 5.8 & 6.3 & 6.9 & 7.2 & 7.2 & 7.3 & 6.8 & 6.4 & 6.0 \\
\hline & S.E. & 0.1 & 0.2 & 0.2 & 0.3 & 0.2 & 0.2 & 0.3 & 0.3 & 0.3 & 0.4 \\
\hline \multirow{2}{*}{$\begin{array}{c}\beta \text {-hCG } \\
(\mathrm{IU} / \mathrm{ml})\end{array}$} & Mean & 6.6 & 7.5 & 7.2 & 7.7 & 8.5 & 9.2 & 8.9 & 7.8 & 6.8 & 6.4 \\
\hline & S.E. & 0.3 & 0.5 & 0.2 & 0.3 & 0.3 & 0.4 & 0.4 & 0.4 & 0.3 & 0.5 \\
\hline \multirow{2}{*}{$\begin{array}{l}\text { Unconju- } \\
\text { gated E } \\
(\mathrm{ng} / \mathrm{ml})\end{array}$} & Mean & 8.4 & 9.4 & 10.4 & 11.6 & 14.0 & 15.9 & 18.8 & 21.4 & 22.4 & 23.4 \\
\hline & S.E. & 0.1 & 0.1 & 0.1 & 0.1 & 0.3 & 0.2 & 0.1 & 0.5 & 0.8 & 1.6 \\
\hline
\end{tabular}

TABLE 2. Correlations among $\beta$ - $h C G, h P L$ and free $E_{3}$ levels in the maternal sera of normal pregnancy

\begin{tabular}{lccc}
\hline & $\begin{array}{c}\beta \text {-hCG } \\
(\mathrm{IU} / \mathrm{ml})\end{array}$ & $\begin{array}{c}\mathrm{hPL} \\
(\mu \mathrm{g} / \mathrm{ml})\end{array}$ & $\begin{array}{c}\text { Free } \mathrm{E}_{3} \\
(\mathrm{ng} / \mathrm{ml})\end{array}$ \\
\hline$\beta$-hCG & & & \\
& & & \\
$\mathrm{hPL}$ & $r=0.853$ & & \\
& $p<0.001$ & & \\
Free $\mathrm{E}_{3}$ & $r=0.152$ & $r=0.302$ & \\
& $p<0.05$ & $p<0.01$ & \\
\hline \multicolumn{4}{c}{$n=155$}
\end{tabular}

TABLE 3. Correlations among birth weight, placental weight and $\beta-h C G, h P L$, free $E_{3}$ levels obtained within one week of delivery in the maternal sera of normal pregnancy

\begin{tabular}{lccc}
\hline & $\begin{array}{c}\beta \text {-hCG } \\
(\mathrm{IU} / \mathrm{ml})\end{array}$ & $\begin{array}{c}\mathrm{hPL} \\
(\mu \mathrm{g} / \mathrm{ml})\end{array}$ & $\begin{array}{c}\text { Free } \mathrm{E}_{3} \\
(\mathrm{ng} / \mathrm{ml})\end{array}$ \\
\hline \multirow{2}{*}{ Birth weight $(n=26)$} & $r=0.291$ & $r=0.232$ & $r=0.727$ \\
& & & $p<0.001$ \\
Placental weight $(n=26)$ & $r=0.622$ & $r=0.798$ & $r=0.745$ \\
& $p<0.001$ & $p<0.001$ & $p<0.001$ \\
\hline
\end{tabular}

observed between $\beta$-hCG and hPL (Table 2). There were highly significant positive correlations between placental weight $(605.7 \pm 19.7 \mathrm{~g}$, mean \pm s.E. $)$ in 27 cases and these three maternal hormone levels which were obtained within a week before delivery as shown in Table 3. Only unconjugated $\mathrm{E}_{3}$ level which was obtained within a week before delivery showed a significant positive correlation with birth weight $(3,450.7 \pm 80.6 \mathrm{~g}$, mean \pm s.E. $), \mathrm{hPL}$ and $\beta$-hCG had not any significant correlation with birth weight (Table 3 ). 


\section{Discussion}

Simultaneous and serial measurement of maternal serum hPL, $\beta$-hCG and unconjugated $\mathrm{E}_{3}$ were performed in 155 samples (27 pregnant women). Same as our result, normative studies have demonstrated a progressive rise in maternal serum hPL levels until 37 weeks' gestation, and thereafter the value remained constant or decrease slightly (Lindberg and Nilsson 1973; Zlatnik et al. 1979; Varner and Hauser 1981). Several investigators have attempted to detect circulating $\beta$-hCG in the plasma of pregnant women (Franchimont and Reuter 1972 ; Ashitaka et al. 1973; Vaitukaitis 1974; Hagen and McNeilly 1975 ; Good et al. 1977; Mputu et al. 1981). They found that the maternal $\beta$-hCG level showed the peak at 12-13 weeks' gestation, after that it remained constant until the end of pregnancy. In this study, we found the small peak of serum $\beta$-hCG at 37 weeks' gestation likewise the peak of hPL. The peak of $\beta$-hCG in late pregnancy suggested that the peak was too small to compare with the peak in the 1st trimester, and even though in late pregnancy, placenta had an ability to produce $\beta$-hCG and that ability might be changed by gestational week. As we previously reported (Furuhashi et al. 1982a, b), we could not show any sex difference for maternal serum $\beta$-hCG level in this study. These data confirmed other investigation (Spellacy et al. 1975).

Numerous publications discussing normal values for serum unconjugated $\mathrm{E}_{3}$ during late pregnancy have depicted a smooth curve which gradually swings upward until term (Cleary and Young 1974; Katagiri et al. 1976; Leuitz and Young 1977). Our results confirmed these results.

In this study, we found highly significant positive correlations among the maternal levels of $\beta$-hCG, hPL and unconjugated $\mathrm{E}_{3}$. There were a few reports that studied simultaneous measurement of maternal serum placental peptide hormones and serum estriol (DeHertogh et al. 1975; Ottesen and Lebech 1979).

Also, we found highly significant positive correlations between these hormone levels within a week before delivery and placental weight, as previously reported (Furuhashi et al. 1982b). On the other hand, birth weight had only a significant positive correlation with the maternal serum level of unconjugated $\mathrm{E}_{3}$. These data suggest that maternal serum levels of $\beta$-hCG, hPL and unconjugated $\mathrm{E}_{3}$ are affected by placental function, and especially that the maternal unconjugated $\mathrm{E}_{3}$ level is more affected than placental peptide hormones with fetal adrenal function. In late pregnancy, these three hormones may change in parallel in normal pregnant women. In previous reports (Franchimont and Reuter 1972 ; Ashitaka et al. 1973; Vaitukaitis 1974; Hagen and McNeilly 1975; Good et al. 1977; Mputu et al. 1981) the maternal $\beta$-hCG level remained constant in late pregnancy, but our data suggest that even in late pregnancy, the maternal $\beta$-hCG level may make a peak but not be constant. 


\section{References}

1) Ashitaka, Y., Nishimura, R., Futamura, K., Ohashi, M. \& Tojo, S. (1973) Serum and chorionic tissue concentrations of human chorionic gonadotropin and its subunits during pregnancy. Endocr.jap., 21, 547-550.

2) Cleary, R.E. \& Young, P.C.M. (1974) Serum unconjugated estriol in normal and abnormal pregnancy. Amer. J. Obstet. Gynecol., 118, 18-24.

3) DeHertogh, R., Thomas, K., Bietlet, Y., Vanderhoyden, I. \& Ferin, J. (1975) Plasma levels of unconjugated estrone, estradiol and estriol of hCS throughout pregnancy in normal women. J. clin. Endocr. Metab., 40, 93-101.

4) Franchimont, P. \& Reuter, A. (1972) Evidence of $\alpha$ and $\beta$ subunits of hCG in serum and urines of pregant women. In: Structure Activity Relationships of Protein and Polypeptide Hormones, edited by H. Margoulies \& N. Greenwood, Excerpta Medica, Amsterdam, pp. 381-387.

5) Furuhashi, N., Suzuki, M., Fukaya, T., Kono, H., Shinkawa, O., Tachibana, Y. \& Takahashi, T. (1982a) Concentrations of LH-hCG, $\beta$-hCG, FSH, estradiol, cortisol and testosterone in cord sera and their correlations. Amer. J. Obstet. Gynecol., 143, 918-921.

6) Furuhashi, N., Fukaya, T., Kono, H., Tachibana, Y., Shinkawa, O. \& Takahashi, T. (1982b) Correlations of birth weights with umbilical cord serum LH-HCG, FSH, $\beta$-hCG, estradiol, cortisol and testosterone levels. Gynecol. obstet. Invest., 13, 241248.

7) Good. A., Ramos-Uribe, M., Ryan, R.J. \& Kempers, R.D. (1977) Molecular form of human chorionic gonadotropin in serum, urine, and placental extracts. Fert. Steril., 28, 846-850.

8) Hagen, C. \& McNeilly, A.S. (1975) The gonadotropic hormones and their subunits in human maternal and fetal circulation at delivery. Amer. J. Obstet. Gynecol., 121, 926-930.

9) Katagiri, H., Distler, W., Freeman, R.K. \& Goebelsmann, U. (1976) Estriol in pregnancy. Amer. J. Obstet. Gynecol., 125, 272-280.

10) Leuitz, M. \& Young, B.K. (1977) Estrogens in pregnancy. Vitam. Horm., 35, 109116.

11) Lindberg, B.S. \& Nilsson, B.A. (1973) Variations in maternal plasma levels of human placental lactogen (HPL) in normal pregnancy and labor. J. Obstet. Gynec. Brit. Cwlth, 80, 619-626.

12) Mputu, L., Thomas, K., Pirens, G., Frankenne, F. \& Hennan, G. (1981) Demonstration of plasma hCG $\beta$-subunit during pregnancy using LH-hCG receptors from immature rat testis. Gynecol. obstet. Invest., 12, 81-92.

13) Ottesen, B. \& Lebech, P.E. (1979) Plasma progesterone, serum estriol and plasma $\mathrm{hPL}$ determinations during the last trimester to detect changes before spontaneous labor. Acta obstet. gynecol. scand., 58, 423-427.

14) Spellacy, W.N., Conly, P.W., Cleveland, W.W. \& Buhi, W.C. (1975) Effects of fetal sex and weight and placental weight on maternal serum progesterone and chorionic gonadotropin concentrations. Amer. J. Obstet. Gynecol., 122, 278-282.

15) Vaitukaitis, J.L. (1974) Changing placental concentrations of human chorionic gonadotropin and its subunits during gestation. J. clin. Endocr. Metab., 38, 755-760.

16) Varner, M.W. \& Hauser, K.S. (1981) Current status of human placental lactogen. Seminars in Perinat., 5, 123-130.

17) Zlatnik, F.J., Varner, M.W., Hauser, K.S. \& Lee, S.S. (1979) HPL : physiologic and pathophysiologic observations. Obstet. Gynecol., 54, 314-317. 